\title{
A Study Sources of Investment in South Sulawesi, Indonesia
}

\author{
Basri Rizak, \\ Lucturer of Muhammadiyah University Makassar
}

\begin{abstract}
This research was done in South Sulawesi. The objectives of this research were (1) To measure the economics performance, the structure and component in relation to the investment needs; (2) to conduct the study of investment sources that able to improve the performance of the economy and ensure the sustainability of development in South Sulawes; and (3) To provide the evaluation matter and a basic consideration for local governments to determine the work program and priorities of activities in order to increase economic growth. The research method was done by using descriptive and quantitative approaches. The research was done in the area of South Sulawesi Province from October to Desember 2011. This analysis uses the results of the statistical approach, the economic, social economic and cultural Metrika by utilizing each model and formula generally known in science disiplimtesebut.Selanjutnya this analysis approach and kuantitaif.Keduadiskriftif this approach gives the same direction but different accuracy levels analysis of diskriftif give a positive direction or a negative or turun.Sedangkan ride and quantitative analysis provides tingkatanya in scale numbers and absolut.Hasilnya seen from the amount of percentage, pictures, graphics, external circle so easy to understand and conclude the results. The result of the study showed that the structure of budget expenditures South Sulawesi Provincial Government, it appears that the value of South Sulawesi government capital expenditure is still not stable and tend to fluctuate from time to time. In addition, if seen from the proportion is still lower than spending on goods and services. This shows that there's more opportunity big enough for the South Sulawesi provincial government to increase the value of investments that are expected to affect the economic growth in South Sulawesi as a whole. In 2007, the value of public deposits in banking institutions in South Sulawesi stood at 23.98 trillion rupiah. Furthermore, just over five years, the number of people saving in banking institutions in South Sulawesi increased to 45.61 trillion or an increase of almost two-fold. The rate of increase in the number of public deposits showed significant revenue growth rate is very large. In addition, the amount of deposits that are large enough to show a willingness to fund substantial investment activities in order to maintain a high economic growth rate.
\end{abstract}

\section{A. Backgroud}

\section{Introduction}

Regional economic development is a process where the local government with the support of communities to manage available resources that are be transformed to the welfare improvement. Such efforts were implementdedby forming partnerships between local governments and the private sector with the full support of the residents.

The main problem in the development of regional economic lies in development policies which based on the uniqueness of the region by exploiting the potential of human resources, institutional and physical resources locally. This orientation leads to taking initiatives emanating from the region in the development process to create new employment opportunities and stimulate increased economic activity.

Regional economic development is a process that includes the establishment of new institutions, the development of alternative industries, improving the capacity of the available labor in order to produce better products and services, identifying new markets, transfer of knowledge and technology, and the development of new ventures.

The main objective of any economic development is to increase the number and types of employment opportunities for local communities. To achieve this goal, local governments and communities should jointly take the initiative of regional development. Therefore, the government with the participation of the community, with the support of existing resources should able to calculate the potential resources needed in order to design and build a local economy.

One of the problems often occure obstacles for the economic development in the region is investment. On the one hand, the resources available in the area is still very plentiful, but on the other hand, the region did not have enough capital to carry out the processing of these resources. The abundance of available resources and lack of capital, is one of the main factors the low level of utilization of production factors.

Harrod-Domar in his theory states that there is a positive correlation between the level of investment to economic growth. With the investment, the existing resources can be harnessed and transformed into goods and services productions with added value. One of the ideas that underlie the preparation of a model that was developed by Sir Roy F. Harrod and EvseyDomar is the need of investment to take advantage for the resources

DOI: $10.9790 / 487 X-181005159174 \quad$ www.iosrjournals.org $\quad 159 \mid$ Page


available so that the factors of production have function. In other words, the investment needed to carry out production activities and in turn will absorb the available labor.

Moreover, the investment is also beneficial to increase total factor productivity in order to maintain the performance of the economy and ensure the sustainability of economic growth. In Sollow Model, an economy that has reached the low phase of diminishing return will experience a slowdown in growth. To overcome this matter, additional capital required to increase total factor productivity so as to create new jobs in order to sustain economic growth and improve the total output in the economy.

In a closed economic system, investment activity to finance development in an area can be overcome from communities savings in the region. Domestic savings may come from the government sector and the community. While in an open economic system, lack of capital investment can be met from abroad (foreign dirrectinvestment).

As one of developing area and and still in a phase of rapid economic growth, South Sulawesi require investment to further enhance the performance of the economy and ensure the sustainability of economic growth. Moreover, the abundance of natural resources still untapped in South Sulawesi, the role of investment as one of the economic driving becomes very important. Given the important role of investment in development, we need a special study on the sources of investment that can be developed to finance economic activities in the region.

\section{B. Goals and Objectives}

Some of the usefulness of the preparation of the study of the sources of investment/Matrix Investments are as follows:

1. Measure the economics performance, the structure and component in relation to the investment needs.

2. Conduct study of investment sources that able to improve the performance of the economy and ensure the sustainability of development in South Sulawesi.

3. As the evaluation matter and a basic consideration for local governments to determine the work program and priorities of activities in order to increase economic growth.

\section{Methodology}

The research was done in the area of South Sulawesi Province from October to Desember 2011. The analysis is defined as a method or technique to parse a problem to know and discover its causes and results as well as future policy direction in order to reimbursing can deliver results as possible. How or techniques in question can be expressed through a statistical approach, economics, econometrics and social culture. These approaches take advantage of each model and formula generally known in the scientific disciplines. Each approach will be different emphases, and therefore ouput can provide the same or different, but a statistically significant difference will not be significant as long as the methods and models used refers to the science of raw standards.

Analysis can also use descriptive and quantitative approach. Both of these analyzes provide the same direction but different levels of accuracy. Descriptive analysis provides a positive direction and the other side or increase or decrease in the negative direction. This analysis is pointing. Quantitative analysis in addition to providing directions also provide level in the scale of absolute numbers as well.Analysis of these results provide firm conclusions in the form of massive amount of analysis and the target in the future. In terms of presentation, the quantitative analysis can be supplemented with the amount of the percentage figures and drawings in the form of pictures and circle graphs or milestone.Supporting information is easier for external parties to know the results of the analysis and conclusion. Further facilitate the steps that will be taken forward.

\section{Fungsional Analysis}

Functional analysis is one method to knowthe relationships between variables that affect an object in a study. The variables declared in the function are the influence factor, and expressed as mathematical variables. Furthermore, the relationship between the variables stated in the form of mathematical relationships, and this mathematical relationship refers to a common relationship. The general relationship may be based on the underlying assumption or to view and take some kind of models that have been perpetrated in other analysis and places. The functional relationships which easily recognized is a linear relationship, where one behavior variable is called exogenous variables, while the object variable is called endogenous. Behavior variable is usually more than one, while object variable only one, because this object is observed.

\section{Impact Analysis (Effect)}

An impact analysis is a way that is intended to determine the cause and effect of an event. An event arising because of other events. When this event or occasion wereexpressed in mathematical form, it was known as variable. Therefore, the impact analysis in principle no different from the function analysis, becausecausal 
events is a causal variables. When applied in the economy, causes of several events are causes of economic variables.

One technique to know the impact of a policy on the economy is to use the ratio model, or more komperensif using input-output tables.

In this study of Sources of Investment (Matrix Investments) using the ratio model to analyze the impact considering the time a relatively narrow. If using impact analysis by Input Output tables requires long time, larger effort and higher cost.

\section{A. Ekonomic Structure}

\section{Economic Overview Of South Sulawesi}

Rostow argued that economic development or transformation process of a traditional society into a modern society is a multidimensionalprocess. Economicdevelopment not only means changes in the economic structure of a region indicated by a decline in the role of the agricultural sector and increase in the industrial sector only.

Tabel2.1 Contribution of Economic Sector of SouthSulawesi in Year 2007-2011

Source: Central Bureau of Statistics

\begin{tabular}{|c|c|c|c|c|c|}
\hline Business Sector & 2007 & 2008 & 2009 & $2010 * *$ & $2011 * *$ \\
\hline 1.Agriculture & 30,17 & 29,4 & 28,0 & 25,83 & 25,32 \\
\hline 2.Mining and excavation & 8,51 & 7,29 & 5,51 & 6,04 & 6,08 \\
\hline 3.Processing Industry & 13,22 & & 12,5 & 12,27 & 12,22 \\
\hline $\begin{array}{l}\text { 4.Electricity, Gas and Water } \\
\text { Supply }\end{array}$ & 1,04 & 9 & 2 & 0,92 & 0,90 \\
\hline 5.Building & 4,63 & 0,98 & 0,95 & 5,54 & 5,65 \\
\hline $\begin{array}{l}\text { 6.Trading, HoteldanRestaurant } \\
\text { 7.Transportation and Com. }\end{array}$ & 15,85 & 5,00 & 5,39 & 17,34 & 17,64 \\
\hline $\begin{array}{l}\text { 8.Finance, Leasing and } \\
\text { Services Company }\end{array}$ & 8,32 & $\begin{array}{l}16,3 \\
4\end{array}$ & $\begin{array}{l}16,6 \\
9\end{array}$ & 8,01 & 7,90 \\
\hline
\end{tabular}

**)TempraryValue

Table 2.1 shows that until 2011 year, the economic structure of South Sulawesi is still based on agriculture. Within five years, the contribution of agriculture to the economy as an average of more than $25 \%$. Nevertheless, the role of the agricultural sector showed a downward trend, which is one indicator of the transformation process in South Sulawesi economic structure from the primary sector to the secondary and tertiary sectors.

The economic sector has the second largest contribution in 2011, while which has role in increasing trend is the services sector. In 2007, this sector contributed $12.05 \%$ to the overall economy of South Sulawesi. Further, the role of this sector in informing Product Domestic Regional Bruto (PDRB) of South Sulawesi is more increasing in subsequent years. In 2011, the role of the services sector to the economy of South Sulawesi reaches $17 \%$. Expansion of the region that has implications for the increase in the number of civil servants thought to be one of the main factors increasing the contribution of general government services subsector which is one of the sub-sectors of the services sector, which in turn have an impact on increasing the contribution of the services sector.

In addition, the sectors have a considerable contribution to the economy are thye sectors of trading, hotel and restaurant. The contribution of this sector relatively stable in the period 2007 to 2011 with an increasing trend. In that period, the average contribution of this sector is $16.77 \%$.

In general, Table 2.1 shows that there has been a shift in the role of the primary sectors (agriculture, mining and quarrying, electricity, gas and water) are replaced by secondary and tertiary sectors in informing PDRB. Such conditions indicate a structural transformation in the economy of South Sulawesi from simple economic structure becomes more advanced. In terms of investment, one of the sectors that need attention is the building sector. Kusuma, Surjaningsih and Siswanto found the building sector is the most dominant sector and has a close relation with the investment. This is because the Indonesian economy is still in the category of developing countries, where most of the activities leading to the preparation of infrastructure such as buildings, roads, bridges, housing and others.

Contribution of the construction sector in the economic structure of South Sulawesi still low. Until the year 2011, the contribution of this sector to the economy of Selataan Sulawesi recorded only by $5.65 \%$. Nevertheless, the construction sector showed growth increasing from year to year. In addition, the relatively small contribution of this sector still provides an indication magnitude of the opportunity to improve the sector. 


\section{B. Economic Growth}

One indicator of the development progress is economic growth. This indicator essentially measures the ability of an economy to increase its output in a faster rate than the population growth rate (Wijono).

During the period 2007-2011, the economic performance of South Sulawesi showed an increasing trend despite slight fluctuations. The economic growth of South Sulawesi in 2007 was recorded at $6.34 \%$. Furthermore, there was a slight contraction in 2009, where economic growth eased slightly to $6.23 \%$. The decrease of economic growth in this year caused by almost all sectors of the economy have decreasing, especially in the mining and quarrying sectorswith the growth up to $4.51 \%$. It was seen that the economic of South Sulawesi was affected by the global financial crisis that occurred in 2009 , resulting in a slowdown in the economy of South Sulawesi.

Tabel2.2 Economic Growth Based Economic Sector in South Sulawesi in Year 2007-2011

\begin{tabular}{|c|c|c|c|c|c|}
\hline Business Sector & 2007 & 2008 & 2009 & $2010 * *$ & 2011** \\
\hline 1.Agriculture & 3,21 & 6,09 & 4,68 & 2,34 & 6,45 \\
\hline 2. Mining & 6,83 & $-2,94$ & $-4,51$ & 15,74 & $-6,47$ \\
\hline excavation & 4,74 & 8,71 & 3,64 & 6,19 & 7,64 \\
\hline $\begin{array}{l}\text { 3.Processing Industry } \\
\text { 4.Electricity, Gas and }\end{array}$ & 8,86 & 12,60 & 8,75 & 8,03 & 8,61 \\
\hline Water Supply & 8,63 & 19,89 & 14,10 & 9,17 & 12,09 \\
\hline $\begin{array}{l}\text { 5.Building } \\
\text { 6.Trading, }\end{array}$ & 9,56 & 11,26 & 10,77 & 11,64 & 10,73 \\
\hline $\begin{array}{l}\text { HoteldanRestaurant } \\
\text { 7.Transportation and }\end{array}$ & 10,15 & 12,54 & 10,20 & 14,82 & 12,11 \\
\hline $\begin{array}{l}\text { Com. } \\
\text { 8. Finance, Leasing }\end{array}$ & 11,54 & 10,37 & 11,21 & 16,79 & 14,84 \\
\hline PDRBbyMigas & 6,34 & 7,78 & 6,23 & 8,19 & 7,65 \\
\hline
\end{tabular}

Source: Central Bureau of Statistics

**)Temprary Value

Meanwhile, in 2011, economic growth was recorded at 7.65\%. On the average economic growth in the last five years amounted to $7.23 \%$. Thus, during the period 2007-2011, the average rate of economic growth in South Sulawesi were higher than the national economic growth rate of 5.93 percent. This indicates that the economic performance of South Sulawesi is better than the performance of the national economy. Growth in the construction sector in South Sulawesi also showed a pattern still fluctuate upward trend from year to year. Moreover, the interesting thing is that the sector is several times had become the leading sector in terms of economic growth rate in South Sulawesi. In 2008 and 2009, the construction sector recorded the largest growth rate compared to other sectors. The growth rate of the construction sector in 2008 and 2009 respectively amounted to $19.89 \%$ and $14.10 \%$. This shows that the construction sector plays an important role in the development of South Sulawesi. In addition, it provides an indication that the level of investment in South Sulawesi is quite high which is characterized by high levels of growth in the construction sector than the average performance of other sectors of the economy.

\section{PDRB perCapita}

PDRB per capita is an indicator that can be used to indicate the level of social welfare in an area at a certain time. This indicator can also be used to indicate the level of population poducivity in an area. Thus, although the PDRB per capita does not reflect the level of income distribution received by the public, but the PDRB per capita remains an important measure to calculate the success rate of development that has been carried out in a region.

PDRB per capita of South Sulawesi from 2007 to 2011 showed an increase from year to year. In 2007, the PDRB per capita amounted to Rp 8,996,056. Subsequently, in 2011, the PDRB per capita of South Sulawesi achieving Rp 16,595,201. Thus, within five years, the PDRB per capita increased by almost two-fold. These conditions indicate the existence of increased prosperity in significant improvements in the last five years. In addition, the increase in the PDRB per capita also showed an increase in productivity in economic activity. 


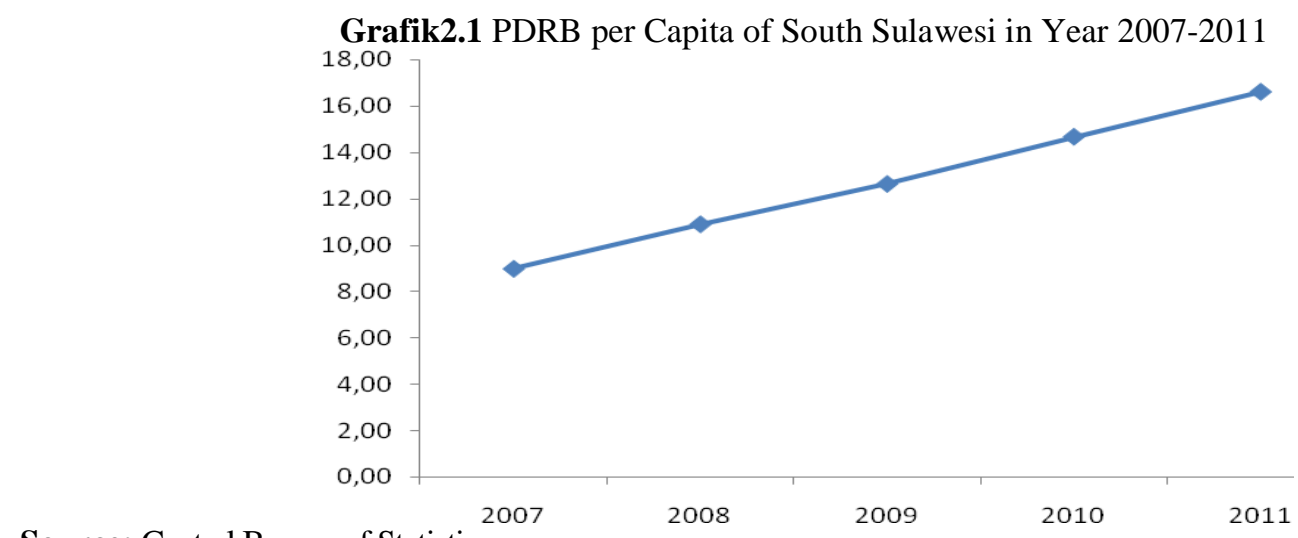

Source: Central Bureau of Statistics

\section{PDRB Based on the Use}

PDRB in usage can also be seen as the PDRB in expenditure. In terms of usage, the PDRB is the sum total output value is used up for economic activity in a region at a specific time period. As for the expenditure side, the PDRB is the sum of consumption is done by all actors in the economy of a region at a specific time period. Components of the PDRB based on expenditure is household consumption, the consumption of private non-profit institutions, government consumption, gross fixed capital formation (investment), changes in inventories and net exports (exports minus imports).

Graph 2.2 shows the proportion of each of the components the PDRB forming based on expenditure in 2011 in South Sulawesi province. From Graph 2.2, it can be seen that the household consumption dominates the formation of PDRB by expenditure (48.23 percent). In other words, the economic of South Sulawesi is highly dependent on household consumption. In the second position, government consumption provides significant contributions, which amounted to 29.46 percent from the South Sulawesi economy comes from the consumption. Furthermore, it appears that the gross fixed capital formation also contributed significantly to the economic structure of the region $(23.66 \%)$.

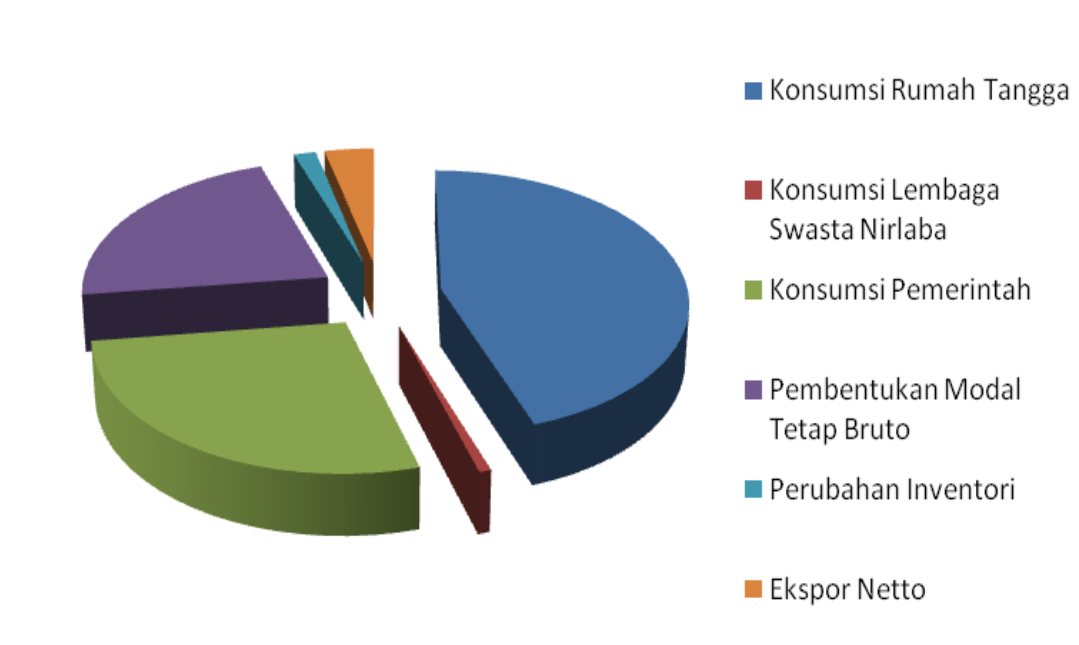

Graph2.2 Distribution of GRDP by Expenditure ADHB South Sulawesi province in 2011

Source: Central Bureau of Statistics

The overall picture shows that gross fixed capital formation (GFCF), which is also defined as an investment has a fairly important contribution to the economy of South Sulawesi. Nevertheless, the development of the real value of GFCF in the period of last five years shows the development tends to decline. In 2007, GFCF growth was recorded at 10.62 percent. Subsequently in 2008, the value of GFCF surged and recorded a growth of $20.66 \%$. However, GFCF growth in subsequent years recorded a decline. In 2011, real growth in GFCF was recorded at $10.20 \%$ (Graph 2.3) 


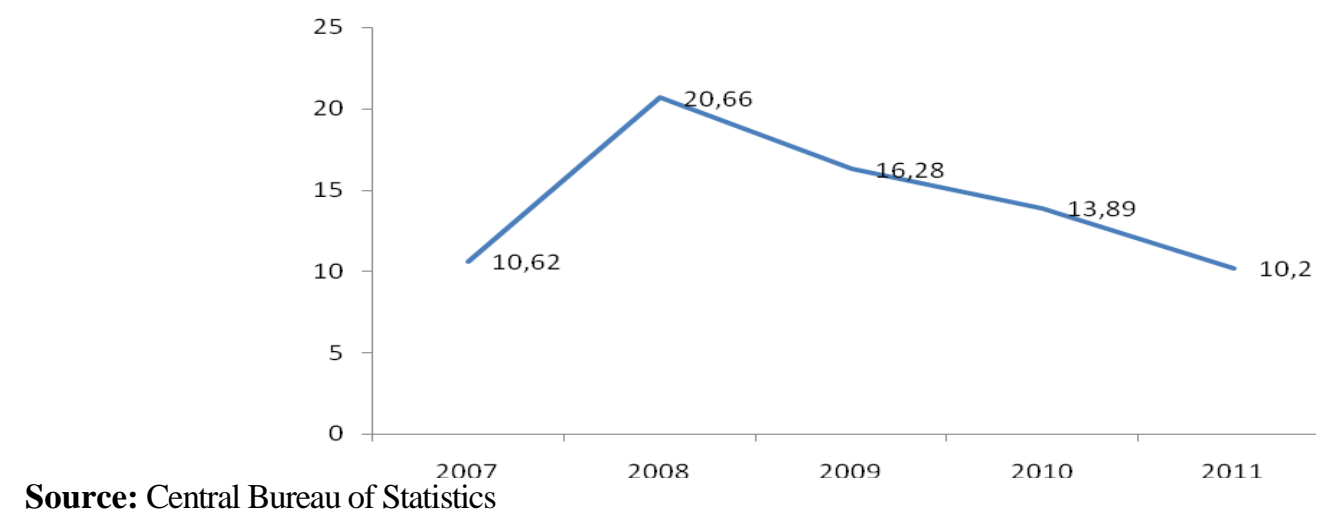

Source: Central Bureau of Statistics

\section{Economic And Socialindicators}

In general, investment is spending to buy capital goods and production equipment with the aim to replace and augment capital goods in the economy that will be used further to produce goods and services (Rustiono, 2008). Dornbusch and Fischer argue that investing is a demand for goods and services to create or increase production capacity or revenue in the future.

Meanwhile, Todaro (1981) argues that the economic development of a region has some general requirements, namely:

1. The accumulation of capital, including new accumulation in the form of land, physical and human resources.

2. The development of the population coupled with the growth of labor and expertise.

3. Advances in technology.

The accumulation of capital will be successful if some part or the proportion of income that is saved and invested to enlarge the product (output) and income in the future. To build it should be necessary to divert the flow of consumption into investment in capital formation in order to achieve greater production levels. In addition, investment in human resource development will enhance the capabilities and expertise of the workforce to become more skilled and expert so as to increase productivity output.

Sukirno (2000) argues that investment activity allows a society constantly increase economic activity and employment, increase national income and improve the prosperity of society. This role comes from three important functions of investment activity, namely (1) investment is one component of aggregate expenditure, so that the increase in investment will increase aggregate demand, national income and employment opportunities; (2) the increase of capital goods as a result of the investment will increase production capacity; (3) investment is always followed by the development of technology.

Suryana (2000) states that a lack of capital that occurred in developing countries occur in several ways, among others: at least the quality and quantity of capital goods to undertake processing activities of existing resources, limited capacity and expertise of the population, the low level of private savings.

As a result of these limitations, the developing countries have abundant natural resources and human resources that many but largely untapped in the position. By him that investment is needed to improve the accretion output of goods and services as well as increase the capacity of human resources. With the growing amount of investment, both by the government and private sector, is expected to spur economic activity in South Sulawesi and will ultimately improve the economic growth impact on the welfare of the community.

In general, there are several economic and social factors that have a significant influence, either directly or indirectly, the level of investment. These factors are:

\section{A. Exchange Value}

Theoretically the impact of changes in the rate/exchange rate with the investment is uncertainty (uncertain). Shikawa (1994), said that the effect of exchange rate change on investment can be direct through multiple channels, exchange rate changes will affect the two channels, the demand side and the supply side of domestic. In the short term, the decline in the exchange rate would reduce investment through their negative influence on domestic absorption, known as the expenditure reducing effect. Due to a decrease in exchange rate will cause the real value of assets of the resulting increase in the level of prices in general, and would also lower domestic demand community. Symptoms of the above at the enterprise level will be responded with a decrease in expenses / allocation of capital investment.

On the supply side, the effect of shifting aspects of expenditure (expenditure switching) will change the rate at the level of investment is relatively uncertain. The decline in the exchange rate of the domestic currency will increase import products as measured by domestic currency and thus will increase the prices of goods 
traded / exported goods (traded goods) relative to goods that are not traded (non tradedgoods ), so we get the fact the exchange rate of the domestic currency will encourage the expansion of investment in items such trade.

As Figure 3.1 shows that in the period 2007-2011 of the rupiah against the US dollar shows a relatively stable trend although slightly fluctuate, especially in 2008 when the subprime mortgage crisis in the United States. Bank Indonesia report shows that in 2007, the average rupiah exchange rate at Rp 9139 per US dollar, or an appreciation of 0.28 percent over the previous year. Until the third quarter of 2008, the exchange rate remained at a relatively stable range of Rp. 9246. Furthermore, in the fourth quarter of 2008, the exchange rate dropped dramatically to USD 11002 per US dollar. The weakening of the exchange rate continues until the first quarter of 2009 as the impact of continued global financial crisis.

However, since April 2009, the exchange rate again showed the upward trend to reach an average of Rp 9548 per US dollar by the end of 2009. The strengthening of the rupiah, which began in 2009 continued into the first quarter of 2011. The process of global economic recovery and increased Indonesia encourages investment grade rating increasing influx of foreign capital inflows into the domestic financial market that supports the strengthening of the rupiah.

Graph3.1.Developments Exchange Rate Year 2007 - 2011

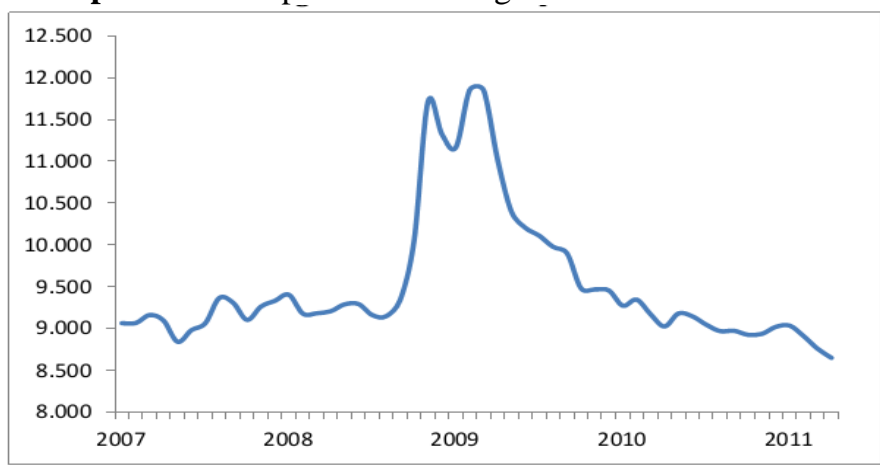

Sorce: Indonesian Bank

\section{B. Interest Rate}

Nopirin (1996) argued that the interest rate is the cost to be paid by the borrower on the loan is received and a consideration on the lender on investment. In other words, the interest rate is the remuneration of the capital / money. Interest rates can be divided into two, the nominal interest rate and real interest rates. Nominal interest rate is rateyang can be observed in the market. While real interest rates is a concept that measures the real interest rate after the nominal interest rate minus the expected inflation rate.

When viewed from the monetary policy, investment is more influenced by real interest rates. And real interest rates are influenced by the SBI rate. When the SBI interest rate higher then real interest rates will also be high so that people prefer to keep their money in banks rather than investing and vice versa, if the SBI interest rate is low, the owners will be inclined to invest money rather than save their money in banks.

With rising interest rates SBI (BI rate), automatic domestic banks will likely raise interest rates, both lending rates and deposit rates, which then may affect investment. As a component that encourages investment, interest rates should be low, low interest rates may encourage investors to make loans to the banking institutions to increase investment, both new investments and business expansion. But the investment can be attractive if interest rates rise. Miraza (2006) found that higher interest rates could increase the cost burden.

Graph 3.2 shows the development of the SBI interest rate, the average interest rate for working capital and investment loans from national banks over the period 2007 to 2011 . The graph shows that Bank Indonesia tried to maintain the BI rate at a positive level with a downward trend and relatively stable in the last five years. In 2007, the national economy is relatively stable so the average SBI stood at 8.04 percent. In the following year, SBI has increased to at 9.34 percent as a result of the rise in inflation in 2008. Furthermore, in tahun2009, SBI interest rate decreased to 7.59 percent. SBI interest rates continued to decline in 2010 amounted to 6.57 percent. And in 2011, the BI rate was recorded again decreased to around 6.5 percent. On average, in the last five years, SBI stood at 7.61 percent. 
Graph3.2.Developments Exchange Rate Year 2007 - 2011

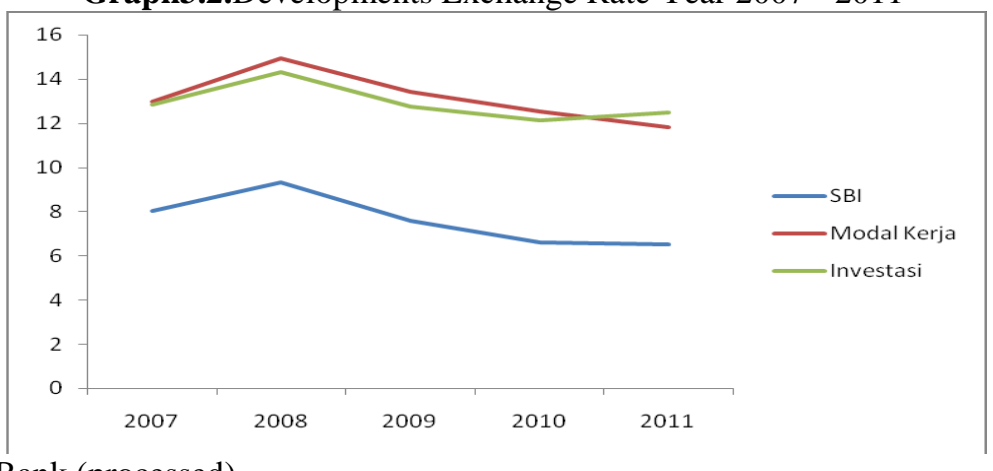

Source: Indonesian Bank (processed)

Meanwhile, the loan interest rate is good for working capital and investment also showed a downward trend follows the movement of SBI rate. In 2007, the average interest rates on loans from domestic banks for working capital and investment interests respectively by $13 \%$ and $12.84 \%$. Subsequently in 2008 , lending rates have increased in anticipation of central bank measures which increase the BI rate to $14.95 \%$ for loans for working capital and $14.32 \%$ for investment. In 2009, interest rates for working capital and investments respectively decreased amounted to $13.41 \%$ and $12.75 \%$. Similarly, in 2010, where the interest on loans for working capital and investments amounted decreased to $12.54 \%$ and $12.11 \%$. As in 2011, interest rates on loans for working capital to continue the trend of decline following the trend of decline in BI rate amounted to $11.82 \%$. By contrast, in the same year, interest rates on loans for investment actually increased to $12.47 \%$.

In general, the development of interest rates on loans for working capital and investment showed growth continued to decline following the steps BI in an effort to reduce interest rates in order to encourage investment. However, that need attention are the trend was not followed by the difference between the BI rate and lending rate. Within five years, the gap between the interest rate and lending rate of SBI would indicate an increasing trend. It shows the high costs of obtaining investment capital that could hinder the investment climate in the national economy in general and the economic performance of South Sulawesi in particular.

At the end of 2011, two foreign rating agencies upgraded the ratings of foreign currency long term (risk level for berinvesatasi in a country in the long term) to investment grade (investment grade). This reflects the resilience of national economic growth, low public debt ratio, strengthening external liquidity and the macroeconomic framework wise (prudent). The condition is a positive signal for the development of investment in Indonesia and South Sulawesi along with the increasing confidence of foreign parties.

However, the financial crisis that occurred on the European continent is still not clear need attention. This is because the financial crisis has an impact on the drying up of liquidity in the global financial markets resulted in flaws in foreign capital inflows. Thus these conditions require that the capital factor in the country still needs to gain greater focus.

\section{Inflation Rate}

The inflation rate have negative effect on the level of investment, it is due to the high inflation rate will increase the risk of investment projects and long-term high inflation can reduce the average time fell to borrow capital and lead to distortion of information about relative prices. Besides, according to Greene and Pillanueva (1991), the high inflation rate is often expressed as the size of the wheels macroeconomic instability and an inability of the government to control the macro-economic policy.

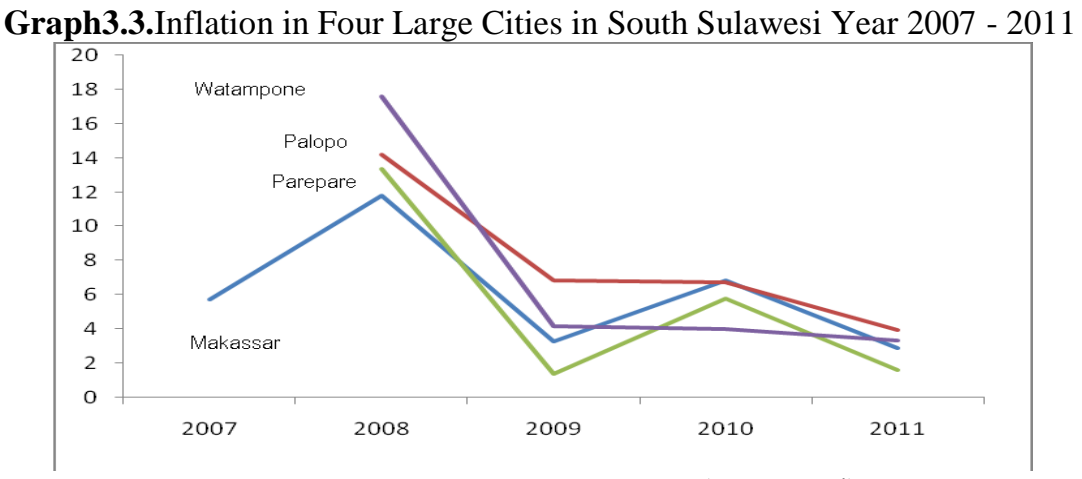

Source: Central Bureau of Statistics (processed) 
Indonesia's inflation rate large enough will usually be followed by the increase in bank interest rates. It is understandable, in an attempt to lower the inflation rate rises, the government often uses monetary policy tight money (tight money policy). Thus the domestic inflation rate also affect investment indirectly through its effect on domestic interest rates.

Figure 3.3 shows the level of inflation in the four major cities in South Sulawesi in the period 2007 2011. In general, the rate of inflation in South Sulawesi shows fluctuations from year to year with a downward trend. In 2008, the inflation rate in the city of Makassar, Watampone, Pare Pare and Palopo looks quite high. Watampone is a city with the highest increase in price when compared to other cities in South Sulawesi. Watampone inflation rate was recorded at 14.22 per cent in 2008. Furthermore, in 2010, the inflation rate back has increased, especially in the city of Makassar and Pare Pare. By contrast, in the same year, the price level of goods and services in the City and PalopoWatampone experienced a small decline.

Meanwhile, developments in the society declined in 2011 in four major cities in South Sulawesi. Parepare listed as the city with the lowest inflation rate in 2011, while the inflation rate is the highest Watampone during the year.

Overall, in the period 2007 - 2011, the average inflation rate is lowest in Parepare, where the average price changes amounted to 5.53 percent. Meanwhile, the highest inflation rate in the same period recorded in the city Watampone by 7.94 percent.

The inflation rate continues to decline from year to year shows South Sulawesi macroeconomic conditions that are well developed. With the movement of goods and services prices were declining, it is indicated in the field of macroeconomic policies quite effectively and also provide a positive signal for the development of investment in South Sulawesi. This condition should be maintained for the creation of a more robust economic performance.

\section{Infrastructure}

Infrastructure is a physical system that provides transportation, water, buildings, and other public facilities are required to meet basic human needs economically and socially (Tanimart, 2008). Infrastructure is basically a government asset that was built in order to give service to the community. In general, there are two types of infrastructure, namely the central and local infrastructure. Center infrastructure is the central government infrastructure built to serve the needs of society on a national scale, such as inter-provincial highways, ports, airports, electricity, gas networks, telecommunications and so on. Infrastructure is an infrastructure built area of local government, such as the provision of clean water, a typical way for the benefit of the tourist areas and so forth. Judging from its function, the infrastructure also differentiated into two, namely infrastructure that generate revenue and non-revenue generating. The first type of infrastructure, commonly used group of a particular community, where the facilities provided, the user community charge. Such as clean water, electricity, telephone, travel cropping and so on. The second type of infrastructure, provision, to enjoy the general public, such as roads, bridges, irrigation channels and so forth so that users are not charged (Marsuki, 2007).

In terms of investment, Mankiew (2004) argued that the workers would be more productive if they have tools to work. Equipment and infrastructure used to call menghasilkanbarang and services in physical capital. The same thing also expressed by Todaro (2000), which explains that the availability of infrastructure in a country is an important and determining factor for the rate of speed and the expansion of economic development. A study by Permana and Alla (2010) indicates that the variable infrastructure including paved road length effect on investment. With good infrastructure, the production process to distribution to consumers will be shorter so that the activities to be efficient. If the state of the infrastructure is still not experiencing a significant improvement trend to decrease then it is thought to be one of the causes of low competitiveness and investment attractiveness. In line with this, Firdaus in (Permana and Alla 2010: 18) argues that the supply of electric power and social infrastructure significantly influence the investment attractiveness of the region.

In addition, rebuilding infrastructure appears to be an alternative option that can be taken by the government in order to tackle the crisis. Infrastructure development will absorb a lot of labor which in turn will affect the local economy increasing passion. With adequate infrastructure, the efficiency achieved by the business world is even greater and increasing investment obtained.

One proxy indicator to determine the condition nfrastructure had in a region is a condition of the road is a means of public transport plays an important role in economic activity. Until the year 2011, of approximately 32432 kilometers long road in South Sulawesi, the majority (91.32\%) are the district / city roads. The length of a long country road and provincial road each as much as 4.80 percent and 3.89 percent (Graph 3.4.). The condition shows that the largest proportion of roads in South Sulawesi is a district / city roads. It is expected the responsibilities and operations of existing roads become faster and more efficient because it can be handled directly by the local government. 
Graph3.4.Percentage Length of State, provincial and regency/city in 2011

Source: Central Bureau of Statistics (processed)

As seen from the road surface conditions that exist in South Sulawesi as much as $51.27 \%$ have been asphalted. The road surface gravel as much as $22.45 \%$, and the road surface is still a dirt road was recorded at $21.21 \%$. While the rest, as much as $5.07 \%$, undefined.

Road infrastructure as a means of public transport in South Sulawesi is still largely are in poor condition. Only half of the length of road surface have been asphalted. While others are still a dirt road or gravel road. It needs serious attention given these conditions can inhibit economic activity that can also affect the investment interest of the investors.

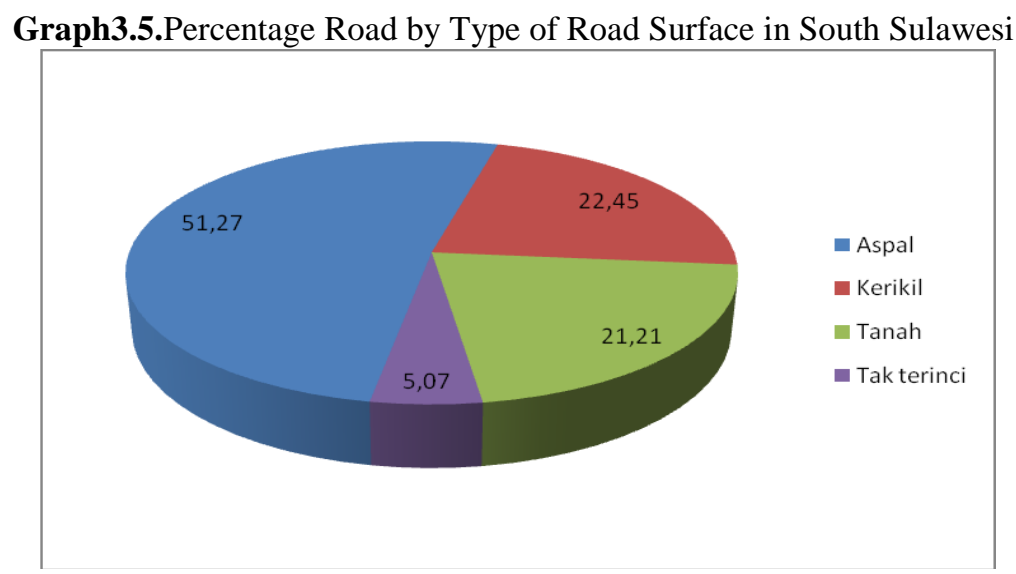

Source: Central Bureau of Statistics (processed)

\section{E. Human Resources}

Stiglitz (1996) argues that the pace of economic growth in developing countries is influenced by the accumulation of capital. Stiglitz refers to its opinion to the economic growth in Hong Kong, Indonesia, Japan, Korea, Malaysia, Singapore, Taiwan, and Thailand, which is based on the rapid flow of investment, especially foreign investment. Furthermore, Cheng (1995) states that the high investment growth rate is highly influenced by human resources.

Human resources play a major role in the uptake of the technology that comes along with investment. With the quality of human resources, developing countries are becoming a new force in the global economy does not face constraints in the absorption of advanced technologies that become the main engine driving the economy. The statement was supported by Heckman (2003) which showed that workers with higher levels of education have the ability to absorb modern technology and with better knowledge and applying it to the local situation. This in turn encourages better economy rate.

One indicator that can be used to measure the quality of human resources in the region is the literacy rate $(\mathrm{AMH})$. $\mathrm{AMH}$ is useful to provide a picture of the ability of the region to absorb information and communicate. Thus, the indicator AMH could be used to determine the quality of absorption and adaptation of the population to new technology coming as the implications of the investment. 


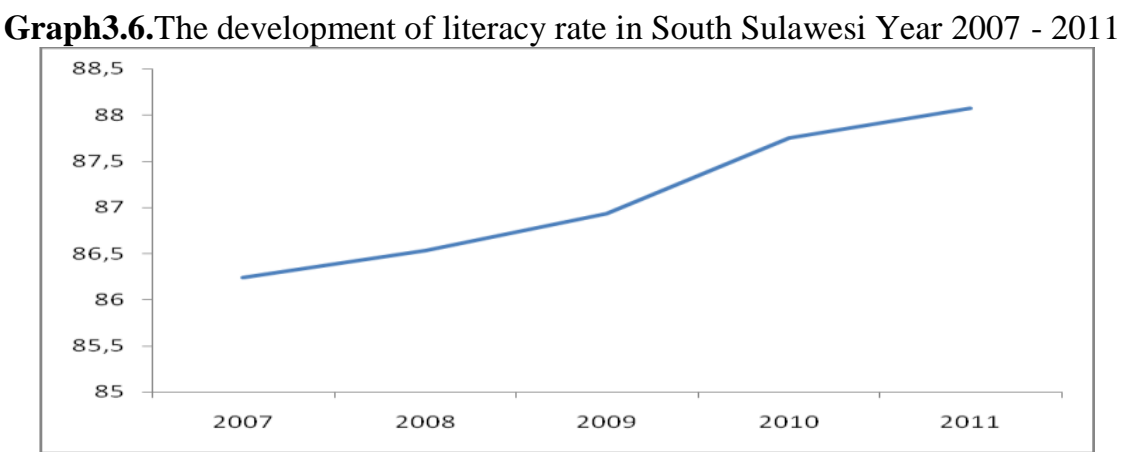

Source: Central Bureau of Statistics (processed)

Graph 3.6 shows the development of AMH South Sulawesi's population during the period 2007 - 2011. It appears that AMH indicates an increasing trend from year to year. A drastic improvement seen in 2010, where the literacy rate was recorded at 87.75 percent of the total population aged 15 years and over from the previous as much as 86.93 percent. This indicates a very good development, which gives an idea of the quality of human resources in South Sulawesi is increasing. It is expected to increase the flow of investments to the economy of South Sulawesi.

\section{Sources of Investment}

To support the development activities, investment activities required to ensure availability and addition of capital goods needed in the economy in a region. In addition, investments were also essential in order to maintain the economic growth and ensure the sustainability of development. Thus, investment activity has a very important role in the economic system in an area.

In general, there are two main sectors that can be relied upon in investment activities in order to ensure the sustainability of the economy. The first is the private sector, both domestic and foreign private sector, and the second is the government sector. Both of these sectors have a role and a different orientation in investment activities. The private sector tends to be profit-oriented for the company, while the government is more oriented to the common good. Nevertheless, both sectors must be synergized to get the optimum benefit to the economic growth and well-being of the wider community.

\section{A. Government Sector}

The investment made by the government gives an overview of the role of government in the economic system in the region. In general, most economists believe that government plays an important role in development activities. Many people who would benefit from the positive economic activity of the government. Furthermore, Todaro (1997) even suggested that the government should be recognized and trusted to acquire a greater role and more decisive in efforts at regional economic management.

The important role of the government should be primarily aimed at investments in infrastructure and social infrastructure that is both mass and less profitable economically. It is, as disclosed by Jones (1976) that infrastructure such as roads, bridges and other infrastructure trasnportasi although not directly contribute to the increase in the value of output but play a strategic role in economic activity.

\section{a. Expenditures}

Table 4.1 shows the amount of expenditures South Sulawesi Provincial Government in 2007 through 2011. Actual expenditures South Sulawesi provincial government during the period of last five showed an increasing trend. The largest increase occurred in fiscal year 2007 amounted to 31.70 percent. While the smallest expenditures occurred in 2009 , with a contraction expenditures by $0.58 \%$ over the previous year. Further expenditures showed an increase. In 2010 and 2011, spending increased expenditures each masig by $17.19 \%$ and $19.55 \%$.

Tabel4.1.Expenditures Government of South Sulawesi province Year 2007 - 2011 (Million)

\begin{tabular}{|l|l|l|l|l|l|l|}
\hline No. & JenisPengeluaran & 2007 & 2008 & 2009 & 2010 & 2011 \\
\hline A. & BelanjaTidakLangsung & 1046425,57 & 1322638,51 & 1236898,97 & 1500511,91 & 1847672,90 \\
\hline B. & BelanjaLangsung & 787341,70 & 811882,06 & 885292,83 & 985647,86 & 1124604,64 \\
\hline 1. & BelanjaPegawai & 102663,74 & 101518,65 & 121502,60 & 122037,64 & 141764,34 \\
\hline 2. & BelanjaBarangdanJasa & 363593,28 & 435182,48 & 467927,55 & 559962,00 & 597017,11 \\
\hline 3. & Belanja Modal & 321084,68 & 275180,94 & 295862,67 & 303648,22 & 385823,19 \\
\hline & JUMLAH/TOTAL & 1833767,27 & 2134520,57 & 2122191,79 & 2486159,77 & 2972277,54 \\
\hline
\end{tabular}

Source: Central Bureau of Statistics (processed) 
Shopping South Sulawesi government expenditure consists of two expenditure items, namely expense/indirect expenditures and direct spending. In the period 2007 - 2011, postal indirect expenditure on average increased $22.69 \%$. The highest increase was recorded in 2007, where the value of indirect expenses increased by $49.09 \%$ to 1.046 trillion rupiah. As in 2009 , the indirect spending contracted by $6.48 \%$.

In the same period, direct expenditure also showed an increasing trend with an average increase of $10.33 \%$ per year. Within five years, the lowest increase occurred in 2008 in which direct spending only increased by $3.12 \%$. The highest increase occurred in 2011, where direct expenditure increased by $14.10 \%$ to 1.124 trillion rupiah.

\section{b. Capital expenditure}

Graph 4.1. The development of direct expenditure component of the Government of South Sulawesi province in $2007-2011$

\section{Source: Central Bureau of Statistics}

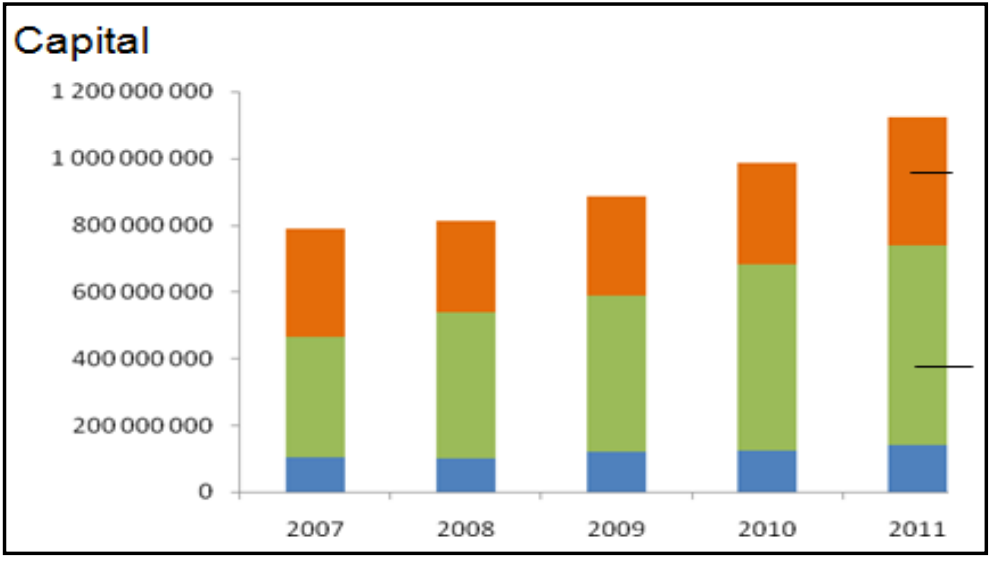

Shopping Goods Shop Employee

The development of direct expenditure components of South Sulawesi Provincial Government during the period 2007-2011 in general show an upward trend from year to year. This also applies to capital expenditure spending component that shows the development continues to increase.

In 2007, capital expenditure amounted to 321 billion rupiah. Then in 2008, capital expenditure amounted to $14.30 \%$ experienced contract to 275 billion rupiah. Subsequently, in 2009, the value of South Sulawesi Provincial Government investment increased to 295 billion rupiah, an increase of $7.52 \%$. The value of investments made by the Government of South Sulawesi province was recorded in 2011, wherein the amount of capital expenditure reached 385 billion rupiah, an increase of $27.06 \%$ from the previous year.

From these conditions, it appears that the Government of South Sulawesi's capital expenditure is still not stable and tend to fluctuate from time to time. In addition, if seen from the proportion is still lower than spending on goods and services. This shows that there's more opportunity big enough for the South Sulawesi provincial government to increase the value of investments that are expected to affect the economic growth in South Sulawesi as a whole.

\section{B. Private Sector}

The existence of the Regional Budget (APBD) which originate from central aid and local revenues is a form of capital accumulation that is used to push the performance of the economy. However there are limitations on the government demanding the participation of private daripihak in investment activity.

In the structure of the economy that are growing, the role of the private sector in investment activity in general remains limited. However, along with increased activity and economic growth, the contribution of the private sector in investment is expected to increase and take a more active role in supporting economic sustainability in the region. At international level, the World Bank even mention that private sector investment plays a very important in creating jobs and economic growth rates are high.

However, there are some things that should receive attention related to the role of the private sector in investment activity. First, private sector investment should be preceded by government investment in infrastructure. The experience of countries that have developed shows that good infrastructure is one of the main attraction of the private sector to undertake investment activities. Second, even though the private sector plays an active role in investment activity are the conditions under which the government is required to regulate and control the economy. It is necessary, especially in terms of procurement of public goods, the conditions in the 
economy where there is a failure of the market (market failure) so that existing resources can not be allocated efficiently, and externalities.

\section{a. Banking}

In relation to economic development, there are two main functions of banking institutions, namely as a service agent (agent of services) and development agencies (agent of development). As a service agency, the bank is one of the institutions that offer services in the financial sector which is closely related to economic activities such as trade, savings and loans, as well as private consumption.

As related to its role as an agent of development, banking institutions have the main activities to collect and distribute funds that is necessary for real economic activity. These activities put banking institutions as mediating institutions for people who want to carry out investment activities. This places the bank as one of the important actors in investment activity in the national economic system. Along with the advance of economic activity in Indonesia, funding agencies for economic activity is also experiencing growth. Financial institutions which have a role in investment activities not only banks, but also increased with the opening of capital markets, credit financing institutions both domestic and foreign investment, as well as other financial institutions. Nonetheless, because of the ease of access and services, banking institutions remain the backbone of the major providers of investment funds in the national economy.

In line with the economic growth rate is increasing in South Sulawesi, the number of banks operating in the region also increased. This shows the strong positive correlation between economic activity and the presence of banking institutions.

Within five years, from 2007 to 2011, the number of bank offices in South Sulawesi has increased by nearly two-fold. In 2007, the number of bank offices in South Sulawesi recorded as many as 323 units consisting of 137 state-owned banks, 52 banks of local government, 132 private national banks and 2 foreign banks and mix. Subsequently, in 2011, the number increased by 91.02 per cent to 617 bank offices. The increase was primarily caused by an increase in its number of government-owned bank of 137 pieces in 2007 to 364 pieces in 2011 (Table 4.2).

Tabel4.2.Total Office of Commercial Banks by Status Ownership

\begin{tabular}{|c|c|c|c|c|c|}
\hline \multirow[b]{2}{*}{ Types } & \multicolumn{5}{|l|}{ Year } \\
\hline & 2007 & 2008 & 2009 & 2010 & 2011 \\
\hline $\begin{array}{l}\text { BankPemerintah } \\
\text { BankPemerintahDaerah } \\
\text { BankSwastaNasionalBankAsingdanCampuran }\end{array}$ & $\begin{array}{l}137 \\
52 \\
132 \\
2\end{array}$ & $\begin{array}{l}144 \\
52 \\
157 \\
3\end{array}$ & $\begin{array}{l}146 \\
52 \\
180 \\
3\end{array}$ & $\begin{array}{l}146 \\
53 \\
189 \\
3\end{array}$ & $\begin{array}{l}364 \\
53 \\
197 \\
3\end{array}$ \\
\hline
\end{tabular}

Source: Indonesian Bank

Growth in the number of bank offices operating in South Sulawesi that provides an indication of the development of South Sulawesi economic performance was very good. In addition, a growing number of banks operating in the region, the investment activity is also expected will be increased and increased. Which in turn will further accelerate the pace of economic growth in South Sulawesi region.

\section{b. Community Savings}

In general, the savings are part of people's income that is not used for consumption. People who have incomes greater than consumption needs will have a chance to save. The savings can be used as one source of funds for investment activities / investment.

Domestic savings in large enough quantities is a source of investment is ideal for investment purposes. This is because domestic savings has the level of risk is relatively small compared to the savings that come from abroad. However, sometimes the amount of domestic savings are very limited in number. So as to overcome these problems, lack of investment taken from foreign financing.

Chart 4.2 shows the development of the value of domestic saving in South Sulawesi from 2007 to 2011. In 2007, the value of public deposits in banking institutions in South Sulawesi stood at 23.98 trillion rupiah. Furthermore, just over five years, the number of people saving in banking institutions in South Sulawesi increased to 45.61 trillion or an increase of almost two-fold. The rate of increase in the number of public deposits showed significant revenue growth rate is very large. In addition, the amount of deposits that are large enough to show a willingness to fund substantial investment activities in order to maintain a high economic growth rate. 
Graph4.2.Development of Deposits South MasyarakatSulawesi Year 2007 - 2011 (Million USD)

Source: Indonesian Bank

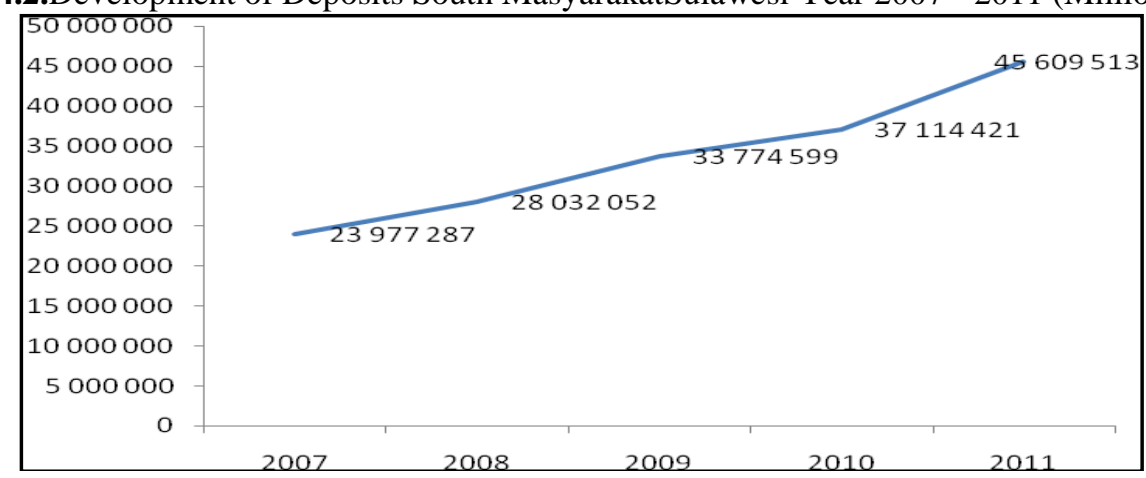

\section{b. Loan Position of BankingInvestment}

Based on data from Bank Indonesia, the value of investment loans granted to economic sectors in South Sulawesi in 2011, amounted to 33.45 trillion rupiah. The amount increased by $37.06 \%$ compared to the number of investment loans in the previous year. When compared with the condition in 2007, an increase in investment credit amounted to $111.10 \%$ in the last five years. On average, the rate of increase of investment loans to sectors of the economy in South Sulawesi amounted to 20.90\% during the period 2007 through 2011 (Chart 4.3). The growth rate of a substantial investment shows that the investment climate in South Sulawesi is very conducive and attractive to the business world. This condition should be maintained so that the high economic growth in South Sulawesi will be sustained in the future.

Graph4.3 Development of Investment Loans in South Sulawesi Year 2007-2011 (million rupiah)

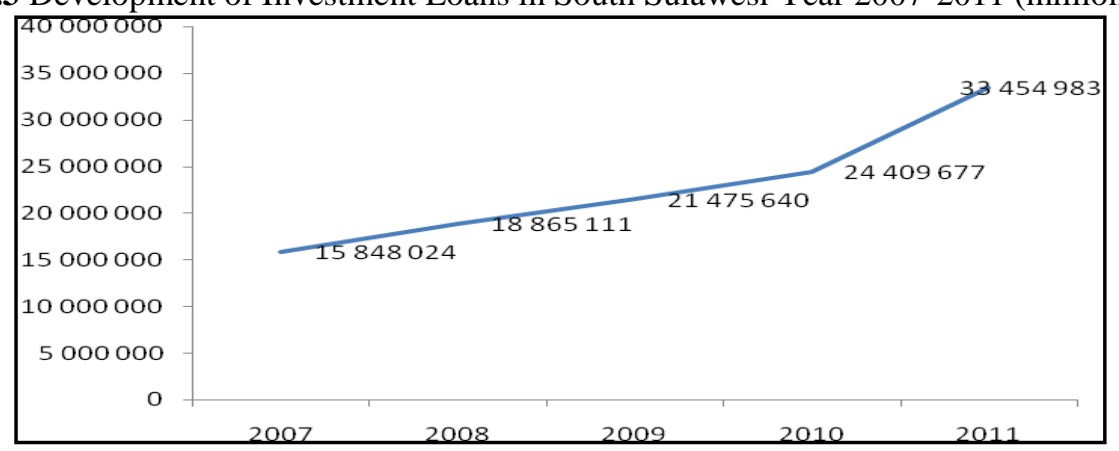

Source: Indonesian Bank

Chart 4.4 shows the distribution of investment loans granted by banking institutions according to sectors of the economy in 2011. From the graph, it appears that the Trade Sector, Hotels and Restaurants absorb investment credit that is greatest among other economic sectors. Of the total loan value of an investment of 33.45 trillion, almost half $(46.34 \%)$ of them are absorbed by the Trade Sector, Hotels and Restaurants. While the rest is absorbed by the eight other economic sectors. Sector Manufacturing and Services including economic sectors are gaining share of loans relatively large investment. The proportion of the value of investment loans for Sector Manufacturing and Services respectively $14.66 \%$ and $12.42 \%$.

Graph4.4 Distribution of Loan Investment by Economic Sector in South Sulawesi in 2011 (percent) 


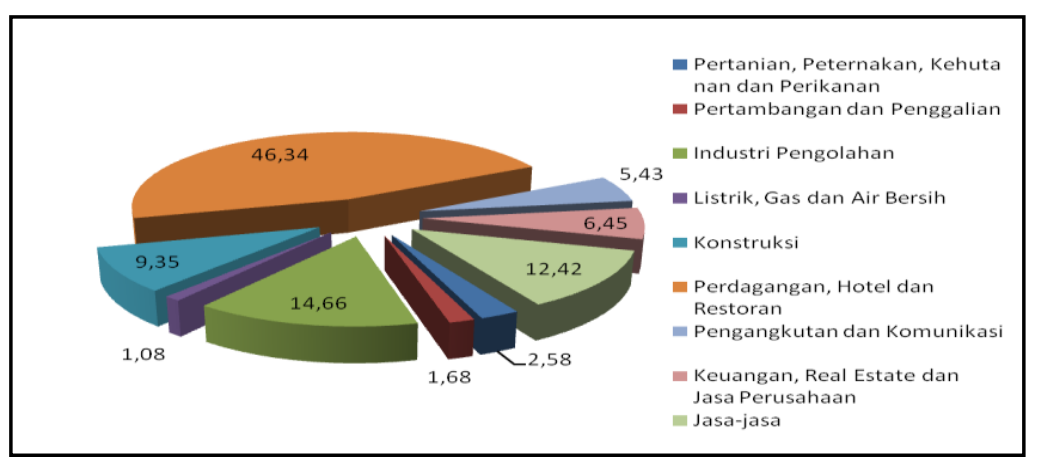

Source: Indonesian Bank

\section{c. Domestic Investment and Foreign Investment}

Value of Domestic Investment (DCI) and Foreign Direct Investment (FDI) in South Sulawesi also showed an upward trend from year to year. Based on data from the Agency for Promotion and Investment Board of South Sulawesi province, the flow of investment both from domestic investors and foreign investors appears to have increased significantly from year to year.

Tabel4.3. Actual value of domestic and foreign investments in South Sulawesi Year 2007 - 2010

\begin{tabular}{|l|l|l|}
\hline Tahun & RealisationPMDN(Rpjuta) & RealisationPMA (US\$ 000) \\
\hline 2007 & $244.670,64$ & $141.430,87$ \\
2008 & $110.524,94$ & $27.696,51$ \\
2009 & $4.461 .424,73$ & $109.172,53$ \\
2010 & $3.212 .295,18$ & $441.796,13$ \\
\hline
\end{tabular}

Source: Agency for Promotion and Investment Board of South Sulawesi Province

During the period 2007 to 2010, the value of domestic and foreign investment is only contracted in 2008 at which time the global financial crisis triggered by the failure of housing loans in the United States. Furthermore, up to 2010, the value of domestic and foreign investment amounting to 3.12 trillion rupiah and 441.80 million US dollars. The increasing value of these investments demonstrate the good performance of the economy of South Sulawesi and the fundamentals of economic structure in the region that attract investors to invest their capital. The amount of investor confidence in investing in South Sulawesi is one of the principal amount for the implementation of sustainable development.

\section{Conclusion}

Investment is spending to buy capital goods and production equipment with the aim to replace and augment capital goods in the economy that will be used further to produce goods and services (Rustiono, 2008). Furthermore, Sukirno (2000) argues that investment activity allows a society constantly increase economic activity and employment, increase national income and improve the prosperity of society.

In general, there are several economic and social factors that have a significant influence, either directly or indirectly, the level of investment. These factors are: 1) The rupiah, 2) The interest rate, 3) Inflation rate, 4) Infrastructure and 5) human resources.

The process of global economic recovery and an increase in the investment grade rating Indonesia to encourage the increasing flow of foreign capital inflows into the domestic financial market that supports the strengthening of the rupiah. The condition is expected to also have a positive impact on the investment climate in South Sulawesi.

In general, the development of interest rates on loans for working capital and investment showed growth continued to decline following the steps BI in an effort to reduce interest rates in order to encourage investment. However, that need attention are the trend was not followed by the difference between the BI rate and lending rate. Within five years, the gap between the interest rate and lending rate of SBI would indicate an increasing trend. It shows the high costs of obtaining investment capital that could hinder the investment climate in the national economy in general and the economic performance of South Sulawesi in particular.

At the end of 2011, two foreign rating agencies upgraded the ratings of foreign currency long term (risk level for berinvesatasi in a country in the long term) to investment grade (investment grade). This reflects the resilience of national economic growth, low public debt ratio, strengthening external liquidity and the macroeconomic framework wise (prudent). The condition is a positive signal for the development of investment in Indonesia and South Sulawesi along with the increasing confidence of foreign parties.

However, the financial crisis that occurred on the European continent is still not clear need attention. This is because the financial crisis has an impact on the drying up of liquidity in the global financial markets 
resulted in flaws in foreign capital inflows. The inflation rate continues to decline from year to year shows South Sulawesi macroeconomic conditions that are well developed. With the movement of goods and services prices were declining, it is indicated in the field of macroeconomic policies quite effectively and also provide a positive signal for the development of investment in South Sulawesi. This condition should be maintained for the creation of a more robust economic performance.

Road infrastructure as a means of public transport in South Sulawesi is still largely are in poor condition. Only half of the length of road surface have been asphalted. While others are still a dirt road or gravel road. It needs serious attention given these conditions can inhibit economic activity that can also affect the investment interest of the investors.

Literacy Rate as a proxy indicator of the quality of human resources showed a very good development, which gives an idea of the quality of human resources in South Sulawesi is increasing. It is expected to increase the flow of investments to the economy of South Sulawesi.

From the structure of budget expenditures South Sulawesi Provincial Government, it appears that the value of South Sulawesi government capital expenditure is still not stable and tend to fluctuate from time totime. In addition, if seen from the proportion is still lower than spending on goods and services. This shows that there's more opportunity big enough for the South Sulawesi provincial government to increase the value of investments that are expected to affect the economic growth in South Sulawesi as a whole.

Growth in the number of bank offices operating in South Sulawesi gives an indication of the development of South Sulawesi economic performance was very good. In addition, a growing number of banks operating in the region, the investment activity is also expected will be increased and increased. Which in turn will further accelerate the pace of economic growth in South Sulawesi region.

In 2007, the value of public deposits in banking institutions in South Sulawesi stood at 23.98 trillion rupiah. Furthermore, just over five years, the number of people saving in banking institutions in South Sulawesi increased to 45.61 trillion or an increase of almost two-fold. The rate of increase in the number of public deposits showed significant revenue growth rate is very large. In addition, the amount of deposits that are large enough to show a willingness to fund substantial investment activities in order to maintain a high economic growth rate.

In 2011, of the total value of investment loans amounting to 33.45 trillion, almost half (46.34\%) of them are absorbed by the Trade Sector, Hotels and Restaurants. While the rest is absorbed by the eight other economic sectors. Sector Manufacturing and Services including economic sectors are gaining share of loans relatively large investment. The proportion of the value of investment loans for Sector Manufacturing and Services respectively $14.66 \%$ and $12.42 \%$.

Meanwhile, the increasing value of investment of foreign and domestic shows the good performance of the economy of South Sulawesi and the fundamentals of economic structure in the region that attract investors to invest their capital. The amount of investor confidence in investing in South Sulawesi is one of the principal amount for the implementation of sustainable development.

\section{References}

[1]. Central Statistics Agency (BPS)South Sulawesi,2012.South Sulawesi in Figures ;2007-2011.

[2]. Dombusch,Rudiger and Stanly Fisher"Economic">New York;Mic.GrawHill.Book Company, 1987

[3]. Harrod.R.F.The Life of John Maynard Keynes.NewYork,Harcourt Brac.1952.

[4]. Investment Board of South Sulawesi,2012.Investment Resources of South Sulawesi,2007-2011.

[5]. Nopirin,2000,EkonomiMoneter,BPFE-Yogyakarta.

[6]. Planning of Development Board South Sulawesi ,2012.Product Domestic Regional Bruto (PDRB) South Sulawesi tahun $2007-2011$.

[7]. Rostow.W.W..Tahap-TahapPertumbuhanEkonomi,diterjemahkan,PaulSitohang.Bhratara,Jakarta 1968.

[8]. SukirnoA.danSritua Arief,1981EkonmiPembangunan;Proses,Masalahdan Keterbelakangan.LembagaStudiPembangunan.Jakarta.

[9]. Samuelson.PaulA.Econmic,Tokyo;MicGraw Hill Kogakisha.Ltd.1980.

[10]. Samuelson and Willem D.Nordhaus"Microeconomics,FoutheenthEdition.Mic.GrawHill.Inc.Air Langga,1999.

[11]. TodaroMichael,P,andSmith,Stephen C .2006 Economic Development,NinthEdition.UK:Person Education Limited. 